\title{
Quality education to succeed the SDGs among college students through the role of learner empowerment and creative self-efficacy to develop innovative work behavior
}

\author{
Arum Etikariena ${ }^{1 *}$ and Pratiwi Widyasari ${ }^{1}$ \\ ${ }^{1}$ Faculty of Psychology, Universitas Indonesia, Depok, 16424, Indonesia
}

\begin{abstract}
Preparing the college students to be ready to perform their innovative work behavior optimally is essential, especially in supporting organizational and national innovation for the SDGs' success. One way is by examining how the students perceive their abilities, potential, and roles in the learning environment. The researchers believe that the relationship between the learner empowerment and innovative work behavior will have a more significant influence when they can also realize the learner empowerment into creative self-efficacy. The research respondents are 539 third semester students or higher from Universitas Indonesia. This quantitative research uses the Innovative Work Behavior Scale, the Learner Empowerment Scale, and the Creative Self-Efficacy Scale. The mediation analysis results show that creative self-efficacy has a partial mediating effect on learner empowerment's relation to innovative work behavior. The three dimensions of the learner empowerment (meaningfulness, competence, and impact) are also significantly related to the innovative work behavior, with the impact as the strongest correlating dimension. This research can be used as input for developing the learning programs, both curricular and extracurricular, to perform innovative work behavior optimally.
\end{abstract}

\section{Introduction}

Innovation has a significant role in determining business success, performance, long-term sustainability, and an organization or company's lifeblood. Innovation also ensures the survival and efforts to achieve corporate/national objectives [1-3]. The basic of innovation is ideas and individuals who develop, carry, react, and modify them. Implementing ideas, which as the most crucial stage in the innovative behavior, takes place in intricate patterns that are sometimes not related to one's environment because it is part of an existing process within the individual [4]. $80 \%$ of innovative ideas come from individuals, and only $20 \%$ arise in the organization [5]. Therefore, it is essential to prepare human resources to perform their innovativeness to support innovation in the organization or nation. However, a survey from the Global Innovation Index Database, Cornell, INSEAD, and WIPO in 2019 showed that the

\footnotetext{
* Corresponding author: arum.etikariena@ui.ac.id
} 
Indonesian people's ability to innovate is lower than in other Asian countries such as Singapore and Malaysia [6]. This information shows the importance of moving individuals to support the achievement of innovation within the organization and their country's benefit. So, it is essential homework for us to contribute to resolving this situation.

Regarding the situation, we propose a study that focuses on students in college. Students are prospective workers or the main actors of innovative work behavior within organizations [3]. Therefore, higher education is a strategic intermediary for developing the students' innovation abilities [7; 8]. This data is also supported by [9], who stated that universities have a more suitable atmosphere for having innovation than the work environment. Therefore, it is essential to prepare the prospective workers since they are still at the high school or university level to perform their innovative behavior when they have become professional workers. [10]. However, most of them are not yet ready to perform their innovative behavior. The learning process that emphasizes "right and wrong answers" only may affect their thinking and acting patterns to become less trained in performing their ability to innovate. Besides, their families' parenting styles, especially in Asian countries, tend only to display authoritarian patterns. It is also considered to hinder the students' creativity [11] because creativity itself is one of the vital components that support innovation [12-14]. The companies expect university graduates as a resource that can help them to be competitive and innovative $[3 ; 15]$.

However, innovative work behavior research is still rarely carried out in the educational field, mostly higher education [13]. So, the result of this study will be one crucial contribution in this area. This study's result can also be a consideration for the universities or company/organization to prepare and build effective intervention preparing the students before they go to work-life. The companies can indeed do several ways to get employees with a high level of innovative abilities by providing training [14], which has been proven to support the emergence of innovative behavior. However, the training also has several weaknesses, such as requiring much money and taking up the employees' productive time. We cannot ensure that the employees who have been given the training will survive in the company for a longer time [15]. Therefore, preparing the students to innovate can help acquire experience while studying, including sharpening their ability to innovate more [3]. The effort to develop innovative work behavior among students also in line with point 4.4 in Sustainable Development Goals (SDGs), especially regarding the quality of education, which stated: "By 2030, substantially increase the number of youth and adults who have relevant skills, including technical and vocational skills, for employment, decent jobs, and entrepreneurship." [16]. By providing education and developing the relevant skills to college students, Indonesia, as a member of the United Nations, engages the youth to actively participate in SGDs and fulfill their commitment to supporting the SDGs [17]. Then, the youth who later become well-prepared workers are expected to participate in succeeding in the future's overall SGDs through their innovative ideas.

From various individual internal factors that influence innovative behavior, this research will focus on specific psychological empowerment, namely the learner empowerment. From psychological empowerment theory, one specific form of psychological empowerment is learner empowerment [20]. Learner empowerment is a condition when the individuals do not only feel a strong motivation to do specific tasks, but they also have a level of control over them [20]. Based on this definition, learner empowerment is more suitable to be applied to the students' population than the psychological empowerment's construct that focuses on the workers. There are three dimensions of learner empowerment, namely meaningfulness, competence, and impact. The empowerment felt by the students is essential because it can help develop their competencies, increase creativity, self-confidence, activity, and intrinsic motivation to succeed [21-23]. In general, the research related to learner empowerment uses almost the same dimensions as the psychological one. Therefore, the research results can be 
used to discuss learner empowerment. From various psychological empowerment studies, it is explained that when the individuals do something by their values and goals (meaningfulness dimension), they feel that their role has an impact on the surrounding environment (impact dimension) and believe in their abilities (competence dimension). They will tend to feel empowered and courageous in performing their innovative behavior [24-27]. Research conducted by [25] stated that the role of the learner empowerment and innovative behavior is significant because an individual's sense of empowerment can facilitate the workflow of the three stages of innovative behavior.

Furthermore, to generate innovative ideas, the learner empowerment needs to be explained more concretely as a condition that can emerge the innovative work behavior. The sense of empowerment within an individual can create a sense of self-confidence to perform these innovative work behaviors. [28; 29] stated that identifying how to develop employees' creative self-efficacy is an essential step for the companies to improve their employees' innovative work behavior. Innovation is a risky behavior [30], so that creative self-efficacy is needed to overcome uncertainty and failure during this innovation process [31]. Therefore, it can be concluded that this creative self-efficacy is an essential internal factor to examine its role in the influence of learner empowerment on innovative work behavior. Therefore, the researchers believe that it is necessary to enforce creative self-efficacy as an individual belief in his ability to mobilize the motivation, cognitive resources, and actions needed to meet the demands of certain situations and to produce something creative or to perform certain tasks in the innovation process $(29 ; 31 ; 32)$. The role of creative self-efficacy as a mediator has been carried out in research conducted by [33]. [34] also have investigated it as a mediating variable between transformational leadership and employee creativity. Therefore, this research will also place the creative self-efficacy as a mediator of learner empowerment's influence on innovative work behavior.

This research was conducted among the students of Universitas Indonesia (UI). Based on research [38], there are some differences regarding the intention to make innovation between business education for students in Indonesia and China. Viewed from an educational perspective, business education in Indonesia does not support the students' intentions to create innovative sense. According to the study, the students of the University of Hohai in China get string support that empowers the students to start a business in the form of facilities, connections, and practical knowledge. In contrast, Indonesia's students are taught theoretical knowledge and do not get adequate help or access that supports their empowerment in starting a business. It is essential to consider that the students are prospective innovative workers needed to compete in the current 4.0 industrial era. Another reason is that the UI students' achievements are still not optimal in presenting their innovative sides. The students' achievement in the Students' Creativity Program (PKM) held by the Directorate of Higher Education since 2001 has not yet shown optimal results. This program is intended to foster, accommodate, and implement the college students' creative and innovative ideas while also bringing a positive impact to society and contributing to the SDGs' success. UI also has National Student Science Week (Pekan Ilmiah Mahasiswa Nasional/PIMNAS) as an event for the students to present their PKM and compete with other students from different universities [39]. Over the past nine years, data have shown that UI students only three times managed to be in the top ten positions. It is not the optimal achievement that UI can achieve, so UI has to improve its student to become an innovative student. As the highest-ranked university in Indonesia based on the SGDs performance, UI can improve their approach in providing education and developing innovative work behavior to their student to give a broader impact to the community to perform innovation more bravely. So, because of the situation that places Indonesian people in the lower rank than Malaysian and Singaporean in innovation and UI students' achievement is still not optimal, we intend to explore this gap more intensively. Thus the hypothesis in this study are: 
H1: creative self-efficacy has a significant mediation effect in the relationship between learner empowerment and innovative work behavior among UI students.

$\mathrm{H} 2$ : there is a significant contribution from each of the dimensions of the learner's empowerment to innovative work behavior.

\section{Method}

This study was quantitative research because we collected data through questionnaires and analysed the data in a quantitative approach. Regarding the research design, this is nonexperimental and a cross-sectional design which only collects the data once [40]. The respondents are undergraduate UI students who are currently undergoing three or more semesters because they have adapted well to both university and surrounding daily life environment. The researchers have targeted approximately 30 respondents from each faculty because [43] stated that a minimum of 30 samples are required to ensure that the data distribution approaches the normal curve. There are 14 faculties for an undergraduate level at Universitas Indonesia, so this research is expected to obtain as many as 420 respondents as a sample size. The respondents were selected using a non-probability sampling method with the type of convenience sampling.

The data are collected by distributing online questionnaires. There are three instruments used in this research, the Innovative Work Behavioral Scale with nine items [2]. This scale contains three stages that consist of idea generation (three items), idea promotion (three items), and idea realization (three items). As a unidimensional variable, the total score from innovative work behavior is used for the analysis [4]. All items will be responded to a Likerttype scale ranging from 1 if the individual has never done it to 6 if the individual always or frequently does. However, because it will be given to the students, some necessary item adjustments are made. An example for idea generation 'Looking for new ways to do my tasks'. Idea Promotion 'I getting support for the innovative ideas I present' and idea realization 'Turning innovative ideas into something that can be used by others'. The scale had a Cronbach's alpha coefficient $=0.88$.

Learner Empowerment Scale was 18 items as a multidimensional construct with three dimensions: meaningfulness, competence, and impact. Each dimension has six items consist of four favorable items and two unfavorable ones. Cronbach's Alpha test results show the reliability coefficient value of 0.87 so that it is reliable for the respondents in the research. An example of the meaningfulness dimension is "Things I learned during the lectures are useful for me". Meanwhile, an example of an item for the competence dimension is "I can go through the lectures well". An example item for the impact dimension and the unfavorable one is "I cannot influence what happens in the lectures". Filling in the questionnaire is a Likert-type scale from 1-6, where one means strongly disagree, and six means strongly agree. Students' creative self-efficacy is measured by the Creative Self-Efficacy Scale arranged by [29]. There are four items with an example item: "I have strong confidence in my ability to solve problems creatively". The scale items responded on a Likert scale starting from 1 if the individual strongly disagrees with the statement to 6 if he/she strongly agrees. the Creative Self-Efficacy Scale had a Cronbach's alpha of 0.83 The regression analysis with the PROCESS was used for mediation analysis [48]. Simple regression is also used to analyze each dimension of learner empowerment's contribution to innovative work behavior [49].

\section{Results and Discussion}

There are 650 participants obtained from filling out the online questionnaire (response rate $=$ $154 \%$ ). However, only 539 responses meet the criteria. A total of 5 respondents checked "not 
willing" to participate in the informed consent section, and 106 do not answer the instructed response items correctly. This data cannot be included in the calculation of data analysis. Based on the data, the respondents' age ranges from 18 to 25 years old $(\mathrm{M}=20.42, \mathrm{SD}=$ 1.13). The dominant gender of the participants is female $(65.7 \%)$. The responses based on the semester show that the distribution of respondents is not much different from the fourth semester $(35.8 \%)$, sixth semester $(28.6 \%)$, and eighth semester $(35.1 \%)$. Most respondents are engineering faculty students with 87 participants $(16.1 \%)$, and the least is from the medical faculty, as many as 13 participants $(2.4 \%)$. Most of the participants (364 students) still live with their parents $(67.5 \%)$. Most respondents participate in some extracurricular activities such as events committee (27.9\%) and campus organizations $(26.2 \%)$.

Table 1. Direct and indirect effects model predictors of innovative work behavior

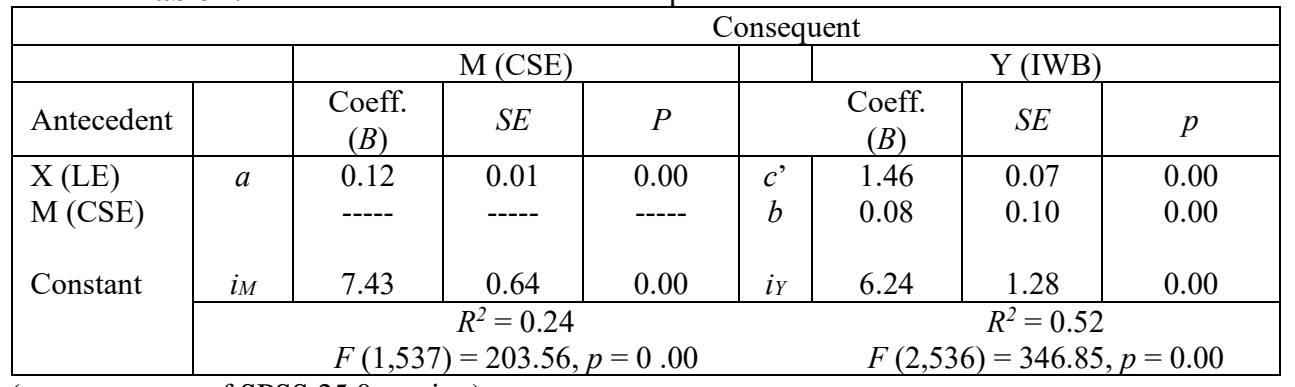

(source: output of SPSS 25.0 version)

From Table 3, it can be seen that when the learner empowerment is regressed on innovative work behavior, there is a significant effect with $\beta=0.12$; BootSE $=0.01$; $\rho<$ 0.001 , BootCl 95\% [LLCI .11- ULCI .14]. Furthermore, when creative self-efficacy is included in the analysis, it can be seen that creative self-efficacy also has a significant mediating effect to explain the effect of learner empowerment on the innovative work behavior, with $\beta=1.46$; BootSE $=0.07 ; \rho<0.001$, BootCl 95\% [LLCI 1.32- ULCI 1.60]). Because both direct and indirect effects have significant impacts, it means that this mediation effect is partial. However, suppose we look at the magnitude of the effect when the learner empowerment is analyzed through the creative self-efficacy on the innovative work behavior. In that case, the effect is much stronger (52\%), compared to only $24 \%$ of the students' empowerment is regressed with innovative work behavior. This result is also explained by the amount of the total effect value, which also shows significant results, where $\beta=0.26, \mathrm{t}$ $(537)=12.89, \mathrm{p}<0.001$, CI95\% (LLCI 0.22 - ULCI 0.30). There is a significant increase when the creative self-efficacy explains the learner's empowerment on the innovative work behavior from a small to a relatively large impact with 10.000 bootstraps. Therefore, the first hypothesis proposed in this research is confirmed by the data.

Following the second hypothesis, regression analysis was implemented to analyze each dimension of the learner empowerment. The results show that the three dimensions (meaningfulness, competence, and impact) significantly correlate. The impact dimension has the strongest correlation $(\mathrm{r}=0.52 ; \mathrm{p}<.01)$ which means it has a large effect size because the $\mathrm{r}$-value is above 0.50 [46]. Meanwhile, as a construct, learner empowerment has an r-value of .46 , which is still classified on medium effect size. The contribution of the learner empowerment is $21 \%$ to innovative work behavior. All learner empowerment dimensions also significantly contribute, with impact as the biggest contribution to innovative work behavior $(\mathrm{r} 2=0.27<0.01)$. It means that a $27 \%$ variance of innovative work behavior can be explained from the impact dimension. 
Table 2. Results of correlation and regression analysis of the learner empowerment dimensions on innovative work behavior

\begin{tabular}{|l|c|c|c|c|}
\hline Variable & $\mathbf{r}$ & $p$ & $\mathbf{r}^{2}$ & $\mathbf{t}$ \\
\hline Learner Empowerment & 0,46 & $0,00^{*}$ & 0.21 & 6.39 \\
\hline Meaningfulness & 0,27 & $0,00^{*}$ & 0.07 & 5.32 \\
\hline Competence & 0,36 & 0,000 & 0.13 & 5.49 \\
\hline Impact & 0,52 & $0,00^{*}$ & 0.27 & 6.05 \\
\hline
\end{tabular}

$* p<0.01$, one-tailed (source: output of SPSS ver 25.0)

This result shows that the feeling of being empowered to learn is necessary for individuals to perform their innovative work behavior optimally $[25 ; 26 ; 50]$. How people feel empowered gives them efficacy that makes them believe that they can do the requirement needed to accomplish their task - this feeling is according to the empowerment perspective $[18 ; 19]$. This analysis also proves that innovative work behavior can be seen and developed among students since they are still studying so that they have more time to practice their innovative abilities and be better prepared to implement their ideas into the work environment in the future [51]. The three dimensions of learner empowerment also have a significant effect on innovative work behavior. The impact dimension has the strongest correlation compared to the other two. It has a more significant role in explaining the relationship between learner empowerment and innovative work behavior. This finding is also found in the research by $[24 ; 25]$ and [52]. Compared to meaningfulness and competence, the impact is a dimension that is directed externally and involves an individual's belief in his ability to influence work processes and results, one of which appears in the form of innovation [52]. The high role of impact on the students can be formed from the campus's learning environment, such as support from the lecturers, classmates, or a university culture that reinforces their innovation [13]. The lecturers or faculty members can increase their perception that the students can influence the learning process by implementing the flipped classroom or student-based learning system implemented in Universitas Indonesia. The students themselves cannot be separated from varied responsibilities such as completing academic assignments every day, starting from individual assignments or group assignments, and adding other tasks such as studying for quizzes or exams. These things can be sources of problems and stress when they cannot complete their duties on time. Moreover, the tasks that must be completed are indeed more than one subject. Having this innovative work behavior then becomes very important for the students because it can become problem-focused coping, which helps them to solve their problems and cope with the stress they feel due to the challenges they have to face [2]. Innovative work behavior allows the students to implement new methods, procedures, or approaches to do better the tasks they need to complete and submit.

The meaningfulness dimension also has a positive and significant relationship with innovative work behavior. Meaningfulness is the process of internalizing a value and belief in the capabilities someone already has [52]. For the students, meaningfulness sees their principles on the meaningfulness of academic tasks [47]. Those who have goals and interests aligned with the learning material and tasks they are doing will be more innovative [22]. Finally, the competence dimension is also significantly and positively related to innovative work behavior. Competence is defined as an individual's belief regarding his ability and understanding to perform various activities proficiently [27]. For the students, competence can be seen from their confidence to undergo and complete the tasks well. Individuals who 
strongly believe in their abilities will dare to conceptualize and realize their innovations [26]. The students who already master the competencies and capabilities will be more courageous in conceptualizing, introducing, and realizing ideas in carrying out their duties.

The researchers have found that creative self-efficacy has a positive and significant relationship with the students' innovative work behavior based on the analysis above. This result means that the higher their creative self-efficacy level, the higher their innovative work behavior will be. Individual creative self-efficacy is related to innovative work behavior because it can provide a strong belief to increase persistence and attitude, which can increase individual self-confidence [29]. This creative self-efficacy enables individuals to overcome uncertainty and failures when trying to solve their problems using their innovative work behavior [31]. Such individuals will continue to think critically to find innovative ideas or solutions. When creative self-efficacy is high, they will spend more time on cognitive processes to generate new ideas. The next stages (promoting ideas and realizing them) will then proceed better and smoother because their high creative self-efficacy has supported them. The individuals can then do a specific job better and achieve innovation goals $[29 ; 31]$. These results are consistent with previous studies, which found a positive and significant relationship between creative self-efficacy and innovative work behavior [31; 32], although much of it is work among the employees, not among the students.

\section{Conclusion}

Even though few studies address the students in innovative work behavior topics, hopefully, this research can give theoretical references regarding innovative work behavior among the students from the psychological empowerment perspective. The results show that learner empowerment can support the emergence of innovative work behavior, mainly explained through creative self-efficacy. The impact of learner empowerment is the most substantial contributor to innovative work behavior among students. The other dimensions also have a significant contribution to consider if we want to develop any program that fosters innovative work behavior. The program can also add the subject that improves creative self-efficacy, so it will significantly impact developing innovative work behavior among college students, especially in UI. So, from this research, it is expected that universities and companies can develop learning programs that involve experiences related to innovative work behavior, likewise, in the case of activities related to extracurricular programs, including relevant training programs. It is expected that this provision will also support point 4.4 in SDGs, where higher education institutions are expected to provide more opportunities for the students to develop their innovative work behavior.

The researchers also suggest that the next researchers expand the samples from other universities to compare this research model in various universities in Indonesia, both state and private. It can also compare the students from the undergraduate level at public universities with those from polytechnic/ vocational colleges. Practical advice that can be given from this research is to consider the results of this research in the form of a learning program for the students so that students can perform their innovative behavior based on the needs of the professional world of work in the future. Some interventions can be done by UI as universities to develop programs to support the students' development in innovative abilities by listening, facilitating, and encouraging them to be more active by providing exciting activities or projects to trigger their innovation. Universitas Indonesia can optimize current existing programs such as the Internship Services Program, Students Creativity Program, and support activities organized by the students' organizations. In increasing students' empowerment, upcoming research can be carried out to compile curriculum and training to improve students' knowledge and skills to feel empowered to generate various innovations. 


\section{Acknowledgements}

This research can be held with support from the Faculty of Psychology Universitas Indonesia through Hibah Riset Dasar 2020 No: 1637/UN2.F8.WDP2K/PPM.00.02/2020. So, we would like to thank you for the valuable support from The Dean and management team of the Faculty of Psychology Universitas Indonesia.

\section{References}

1. U. A., Agarwal, Linking justice, trust and innovative work behaviour to work engagement, Person Rev 43,1, 41-73, (2014) https://doi.org/10.1108/PR-02-2012-0019

2. O. Janssen, Job demands, perceptions of effort-reward fairness and innovative work behaviour, J. Occ. Organ. Psy. 73, 3, 287-302, (2000) https://doi.org/10.1348/096317900167038

3. P. Martín, L, Potočnik. A.B, Fras, A, Determinants of students' innovation in Higher Education, Study in Higher Edu 42, 7, 1229-1243, (2017) https://doi.org/10.1080/03075079.2015.1087993

4. S. G. Scott. R. A. Bruce, Determinants of innovative behavior: A path model of individual innovation in the workplace, Acad. Manag. J. 37, 3, 580-607, (1994) https://doi.org/10.5465/256701

5. I, Getz. A.G. Robinson, Innovate or Die: is that a fact? Creativ. and Innov. Manag. 12,3, 130-136, (2003). Blackwell Publishing Ltd

6. https://katadata.co.id/agustiyanti/finansial/5e9a4e606bfc0/peringkat-daya-saingindonesia-turun-makin-tertinggal-dari-malaysia\#: :text=Peringkat\%20daya\%20saing\% 20Indonesia\%20dalam,poin\%20ke\%20posisi\%2064\%2C6. Diunduh Agustus 2020

7. Y. Chen. Y. Yin, Research on mechanism of innovation climate in college on college student's innovative behavior the mediating effects of intrinsic incentives, 3rd Int. Conf. Arts, Des. Contemp. Educ. ICADCE, 144, 914-917, (2017)

8. G. Messmann. R. H. Mulder, Innovative work behaviour in vocational colleges: Understanding how and why innovations are developed, Vocat. Learn., 4, 1, 63-84, (2011) https://doi.org/10.1007/s12186-010-9049-y

9. X. huan Zhong. Z. liang Liu, Studies on creativity enhancement of contemporary college students,3rd Int. Conf. Sci. Soc. Res. ICSSR, (2014) https://doi.org/10.2991/icssr14.2014 .148

10. A. Etikariena, Analisis efek mediasi identitas keorganisasian dan kesiapan karyawan untuk berinovasi pada hubungan antara ingatan keorganisasian dan perilaku kerja inovatif, Doctoral dissertation, Universitas Indonesia, Depok, Indonesia, (2017), Unpublished. Retrive from: http://lib.ui.ac.id/detail?id=20446751\&lokasi=lokal\#parentHorizontalTab2

11. N.A. Kwang, Why Asians are more less creative than westerners, (2001), Prentice Hall

12. B.A. Hennessey and T.M. Amabile, Creativity", Ann Rev of Psy, 61, 569-598, (2010)

13. S. H. M. Roffeei, F. D. Yusop. Y. Kamarulzaman, Determinants of innovation culture amongst higher education students., Tojet - Turkish Online J. Educ. Technol., 17, 1, 3750, (2018)

14. A. Azevedoa. M.J Shane, A new training program in developing cultural intelligence can also improve innovative work behavior and resilience: A longitudinal pilot study of graduate students and professional employees,. The Intl J. of Manag. Edu, 17, (2020)

15. Reddy, Staff Training: Importance, Benefits, Advantages \& Disadvantages, https://content.wisestep.com/staff-training-importance-benefits-advantages$\underline{\text { disadvantages (2019) }}$ 
16. U. Nations, 4 Quality Education.[Online]. Available: https://www.un.org/sustainabledevelopment/education/\#tab-bec3d6b2e412d024e05 [Accessed: 15-Jul-2020]

17. U. Nations, The 17 Goals: History.[Online]. Available: https://sdgs.un.org/goals [Accessed: 15-Jul-2020]

18. M. A. Zimmerman, Taking aim on empowerment research: On the distinction between psychological and individual conceptions, American J. of Comm. Psy., 18, 169-177, (1990)

19. M.A. Zimmerman, Psychological Empowerment: Issues and Illustrations, American. J. of Comm. Psy., 23, 5. (1995)

20. A.B. Frymier, G.M. Shulman, and M. Houser, The development of a learner empowerment measure, Comm. Edu, 45, 3, 181-199, (1996)

21. T. Batool, G. Noureen, and Z. Ayuob, Relating Learner Empowerment with Learner Self-Regulation Learning in Higher Education, Rev of Eco and Dev. Stud, 5, 4, 755-766, (2019),

22. C. M. Kirk, R.K. Lewis, K. Brown, B. Karibo, and E. Park, The power of student empowerment: Measuring classroom predictors and individual indicators, The J. of Edu. Res, 109, 6, 589-595, (2016)

23. H . Schmidt, C. Baumgarth, Empowerment from a "student as customer" perspective: Literature review and development of a framework in the context of higher education, Res. Gate, (2017)

24. N. Ghani. K. Jusoff, Stimulating lecturers' innovative behaviour in Malaysian Polytechnics, Acad Lead: The Online J, 7, 4, [29], (2009a)

25. N. A. A, Ghani, T. A., Hussin. K, Jussoff, The impact of psychological empowerment on lecturers' innovative behaviour in Malaysian private higher education institutions. Canad. Soc. Sci, 5, 4, 54-62. (2009b)

26. A. A. A, Rahman,., S. A.Panatik. R. A. Alias, The influence of psychological empowerment on innovative work behavior among academia in Malaysian research universities,. Intl. Proc. of Econ. Dev. and Res., 78, 108. (2014)

27. G. M Spreitzer,. Psychological empowerment in the workplace: Dimensions, measurement, and validation, Acad. of Manag. J, 38, 5, 1442-1465, (1995)

28. P. Tierney. S.M. Farmer, Creative self-efficacy development and creative performance over time, J. of Appl. Psy., 96, 2, 277-293. (2011)

29. P. Tierney. S.M. Farmer, Creative self-efficacy: Its potential antecedents and relationship to creative performance, The Acad. of Manag. J., 45, 1137-1148. (2002)

30. F. Yuan. R.W., Woodman, Innovative behavior in the workplace: The role of performance and image outcome expectations, Acad. of Manag. J, 53, 2, 323-342. (2010) .

31. M.L.A. Hsu, S, T. Hou. H. L. Fan, Creative self-efficacy and innovative behavior in a service setting: optimism as a moderator, The J. of Creative Behav., 45, 258-272. (2011)

32. T., Slåtten, Determinants and effects of employee's creative self-efficacy on innovative activities, Intl, J. of Qual. and Serv. Sci, 6, 326-347 (2014)

33. W. Liu. . Y. Pan. X. Luo. L. Wang. W, Pang, Active procrastination and creative ideation: The mediating role of creative self-efficacy, Person. and Indiv. Diff. 119. 227229. (2017)

34. S, Mittal, R.L, Dhar, Transformational leadership and employee creativity, Manag. Decis. 53 5, 894-910. (2015)

35. L.K, Jenaa, .P. Bhattacharyyab, S. Pradhan, Am I empowered through meaningful work? The moderating role of perceived flexibility in connecting meaningful work and psychological empowerment, IIMB Management Review, 31, 298-308. (2019) 
36. N. K. Jaiswal, R.L. Dhar, Transformational leadership, innovation climate, creative selfefficacy and employee creativity: A multilevel study, Intl J. of Hospitality Manag. 51, 30-41. (2015)

37. P., Wang, J.C. Rode, K Shi, Z. Luo, W., Chen, A workgroup climate perspective on the relationships among transformational leadership, workgroup diversity, and employee creativity, Group Org. Manag. 38,3, 334-360. (2013)

38. Y. Kaijun. P.I. Sholihah, A Comparative Study of The Indonesia and Chinese Educative Systems Concerning The Dominant Incentives to Entrepreneurial Spirit (Desire for A New Venturing) of Bussines School Students, J. of Innov. and Entrep., 4, 1, 1-16 (2015)

39. D. Kemahasiswaan, D. J. P. dan Kemahasiswaan, and Kementerian Pendidikan dan Kebudayaan, Pedoman Program Kreativitas Mahasiswa (PKM) Tahun 2020 : Buku 1 Panduan Umum

40. F. J, Gravetter. L. A. B. Forzano, Research Methods for the Behavioral Sciences (4th ed.). Belmont: Wadsworth Cengage Learning. (2012)

41. F.J., Gravetter, L.B. Wallnau,. Statistics for behavioral sciences, (9th Ed). Belmont, CA: Wadsworth, Cengage Learning. (2013)

42. J.Southall, H.Wason, B. Avery, Non-traditional, commuter students and their transition to Higher Education - a synthesis of recent literature to enhance understanding of their needs, Stud. Enga. and Exp. J., 5, 1, 1-15. (2016)

43. C. Trautwein, E. Bosse, The first year in higher education-critical requirements from the student perspective Hig. Edu. 73, 3, 371-387. (2017)

44. A, Etikariena. H Muluk, The correlation between organizational memory and innovative work behavior, Makara Hubs-Asia, 18, 2, 77-88 (2014)

45. P. M Podsakoff. S. B MacKenzie. J. Y Lee. N. P. Podsakoff, Common method biases in behavioral research: a critical review of the literature and recommended remedies, J. of App. Psy., 88, 5, 879. (2003)

46. T. J. B. Kline, L. M. Sulsky, S. D Rever-Moriyama, Common method variance and specification errors: A practical approach to detection The J. of Psy., 134, 4, 401-421. (2000).

47. A. J Berinsky, F.M Michele, M. W Sances, Separating the shirkers from the workers? Making sure respondents pay attention on self-administered surveys, American J. of Polit. Sci. 58, 3, 739-753. (2013)

48. A.F. Hayes, Introduction to Mediation, Moderation, and Conditional Process Analysis: A Regression-Based Approach, 2nd Edition. The Guilford Press. New York. (2018)

49. A. Field, A. Discovering Statistics Using SPSS. (4th ed.). London: Sage Publications Ltd. (2015)

50. M. Singh, A. Sarkar, The relationship between psychological empowerment and innovative behavior, J. of Personl Psy. 11, 3, 127-137. (2012)

51. K. A. Davis, C.T. Amelink, Exploring differences in perceived innovative thinking skills between first-year and upperclassmen engineers, In 2016 IEEE Frontiers in Edu.Conf. (FIE) 1-7 (2016)

52. J .Knol, R.Van Linge, Innovative Behaviour: The Effect of Structural and Psychological Empowerment on Nurses. J. of Advan, Nursing, 65, 2, 59-70 (2009)

53. A. Etikariena, Perbedaan perilaku kerja inovatif berdasarkan karakteristik individu karyawan, J. Psiko., 17, 2, 107-118. (2018) https://doi.org/10.14710/jp.17.2.107-118 